\title{
Temporary Water Holes May Benefit the Breeding of the Common Skipper Frog Euphlyctis cyanophlyctis (Anura: Dicroglossidae)
}

\author{
Mohammad Abdul Wahed Chowdhury*(D), Shimu Rani Shil (D) and Md. Mizanur Rahman
}

check for

updates

Citation: Chowdhury, M.A.W.; Shil, S.R.; Rahman, M.M. Temporary Water Holes May Benefit the Breeding of the Common Skipper Frog Euphlyctis cyanophlyctis (Anura: Dicroglossidae). Ecologies 2021, 2, 138-149. https:// doi.org/10.3390/ecologies2010007

Received: 11 November 2020

Accepted: 29 January 2021

Published: 5 February 2021

Publisher's Note: MDPI stays neutral with regard to jurisdictional claims in published maps and institutional affiliations.

Copyright: (c) 2021 by the authors. Licensee MDPI, Basel, Switzerland. This article is an open access article distributed under the terms and conditions of the Creative Commons Attribution (CC BY) license (https:/ / creativecommons.org/licenses/by/ $4.0 /)$.
Department of Zoology, University of Chittagong, Chattogram 4331, Bangladesh; shimu_shil@yahoo.com (S.R.S.); mizancu103@gmail.com (M.M.R.)

* Correspondence: wahed.chowdhury@cu.ac.bd

\begin{abstract}
Seasonal fluctuations in adult Euphlyctis cyanophlyctis density were recorded in two permanent ponds in Southeastern Bangladesh. From a two-year dataset of seven habitat parameters, the seasonal suitability of two different pond habitats was examined to understand these fluctuations of frog density. The combined influence of the parameters on the density was significant in all three seasons. One combination was found to be optimal: water temperature of $24^{\circ} \mathrm{C}$, a pH of approximately 6, and a water depth of $2.29 \mathrm{~m}$. These conditions supported more than 24 frogs per acre in the round pond. In the forestry pond, the optimal parameters were a water temperature of $27^{\circ} \mathrm{C}$ and a water depth of less than $1 \mathrm{~m}$, which accommodated 27 frogs per acre. The result indicates that a slight increase in any of these parameters was found to sharply lower the accommodation capacity of the studied ponds to less than half of the aforesaid densities, especially in the rainy season. During this season, the adults were found to breed in the small waterholes adjacent to the ponds. This may be the response of anuran to temporal unsuitability, for example, the depth of water and the $\mathrm{pH}$ of the permanent ponds.
\end{abstract}

Keywords: habitat; parameter; population; null abundance; pond; temporary water hole

\section{Introduction}

Studies on amphibian populations and habitats have become a major research interest of ecologists in order to uncover the reasons for the rapid extinction of amphibians globally [1,2]. How amphibian populations behave over a short period, viz., seasons, in a variety of habitats has also been studied [3,4]. The seasonal conditions of habitats can explain anuran population fluctuations [5]. Moreover, unfavorable habitat conditions may affect the metamorphosis of tadpoles [6], which may cause the low abundance of a population [7]. This can lead to the sudden extinction of amphibians in a habitat [8]. Synergistic interaction of parameters, pathogens, and warm-dry environments was associated with the sudden decline of Atelopus ignescens in inter-Andean valleys [9]. For amphibians, basic conservation activities should focus on preventing changes in suitable habitat conditions that result in poor accommodation capacity of a habitat.

Being amphibious, aquatic parameters play an important role in every part of the anuran life cycle. Water temperature has a profound influence on development and growth in the embryonic and larval stages of anurans $[10,11]$. Embryos at constant temperature $\left(15{ }^{\circ} \mathrm{C}\right)$ hatched earlier than those in fluctuating temperatures $\left(4^{\circ} \mathrm{C}\right.$ to $\left.15^{\circ} \mathrm{C}\right)$ [10]. For breeding, the adult anurans usually select habitats with suitable parameters. For example, Bufo calamita choose breeding sites with a $\mathrm{pH}$ above 3.8 (3.8-6.9) [12]. Dissolved oxygen also influences the choice of breeding pools [13]. Pearman [14] studied the multilevel influence of the size of the water body — calculated from the pond surface area and depth-on tadpole populations of Rana clamitans. Increased area and depth of the water bodies led to lower survival in tadpoles of this species [14]. 
In Bangladesh, about $20 \%$ of amphibian species are categorized as threatened, and the biggest threat is habitat alteration [15]. However, studies on amphibian habitats and populations in Bangladesh are limited [16]. The largest portion of the recently published research has focused on genetic analyses [17], description of new species [18], or work on amphibian communities in a specific locality [19]. Those studies have enriched the list of amphibians of Bangladesh by adding more than 23 new records in the last 15 years [15]. Of the anurans, the common skipper frog, Euphlyctis cyanophlyctis (Schneider, 1799), is a species complex $[17,20]$. Seven new species have already been described; they were previously included under the single taxon E. cyanophlyctis $[18,21,22]$. In our study, we considered the lentic-occurring E. cyanophlyctis. This aquatic frog is active both day and night all around the year, and they usually inhabit any water body. Adults are voracious feeders of surface insects, and tadpoles are organic component feeders from the bottom of the water body. Adult breeds mostly in the rainy season (July through September) [15]. The population dynamics of this freshwater skipper frog is unknown [15]. A wide fluctuation in the population of the common skipper frog with a lack of sightings was recorded in seven different water habitats in southeastern Bangladesh in 2013 [23] and three in 2014 [24]. Another study in 2015 recorded similar absences and wide population fluctuations of this species (0-51 individuals/acre) in three ponds in the same area [25]. To understand this phenomenon, we studied seven habitat variables of those ponds in 2013 and in 2015.

In the present study, we analyzed the influence of habitat variables on the accommodation capacity of two permanent pond- habitats. We will test the hypothesis that variations of the variables shape the seasonal suitability of the habitat and the seasonal density of adult frogs as the response variable. Moreover, we compared the habitat suitability based on the cumulative influence of the variables between breeding seasons and non-breeding seasons.

\section{Materials and Methods}

The study area, Chittagong University Campus, includes over seven square kilometers of land between $22^{\circ} 27^{\prime} 25.69^{\prime \prime}$ and $22^{\circ} 27^{\prime} 26.34^{\prime \prime} \mathrm{N}$ and between $91^{\circ} 48^{\prime} 10.12^{\prime \prime}$ and $91^{\circ} 48^{\prime} 10.96^{\prime \prime} \mathrm{E}$. This area-situated in Hathazari Thana of Chattogram division in Bangladesh-includes the hilly terrain of the Sitakunda hill range and plains [26] (Figure 1). Two permanent water bodies were selected to represent the perennial lentic water bodies of this area. Structurally, both ponds have a steep bank, though some eroded parts of the bank formed slopes. The depressions surrounding these water bodies and the poorly maintained drainage frequently turn into temporary waterholes [26] in which E. cyanophlyctis can be observed during the monsoon season. The littoral sediments of the ponds are predominantly sandy with clay [27]. The land adjacent to the ponds is mainly used for plantation.

\subsection{Site-1 (Round Pond)}

This study site is a round perennial pond $\left(22^{\circ} 27^{\prime} 58.1^{\prime \prime} \mathrm{N} 91^{\circ} 47^{\prime} 31.4^{\prime \prime} \mathrm{E}\right)$ with a surface area of 0.59 acres and $55 \mathrm{~m}$ diameter. The mean depth is $2.55 \mathrm{~m}$, and the edges are vertical. An exit pipe expels excessive water. The bank is heavily vegetated by native shrubs along with planted coconut (Cocos nucifera) and mahogany trees (Swietenia mahogany). Rainfall and seepage are the main sources of the refill.

\subsection{Site-2 (Forestry Pond)}

This is a triangular pond $\left(22^{\circ} 27^{\prime} 44.3^{\prime \prime} \mathrm{N} 91^{\circ} 47^{\prime} 46.6^{\prime \prime} \mathrm{E}\right)$ of 1.5 acres in size with a mean depth of $0.79 \mathrm{~m}$. The bank of this pond is characterized by a hill slope with planted teak (Tectona grandis) and dense undergrowth of climbers and shrubs on one side. The ornamental plant false ashoka (Polyalthia longifolia) dominates another side. This pond also has a pipe to expel excessive water.

The area is subject to a tropical maritime climate with three main seasons: a humid summer from March to May, a tropical Monsoon from June to October, and dry winter from November to February [28]. The semi-evergreen forest of the campus consists of 665 plant species from 126 families and 404 genera [29]. 


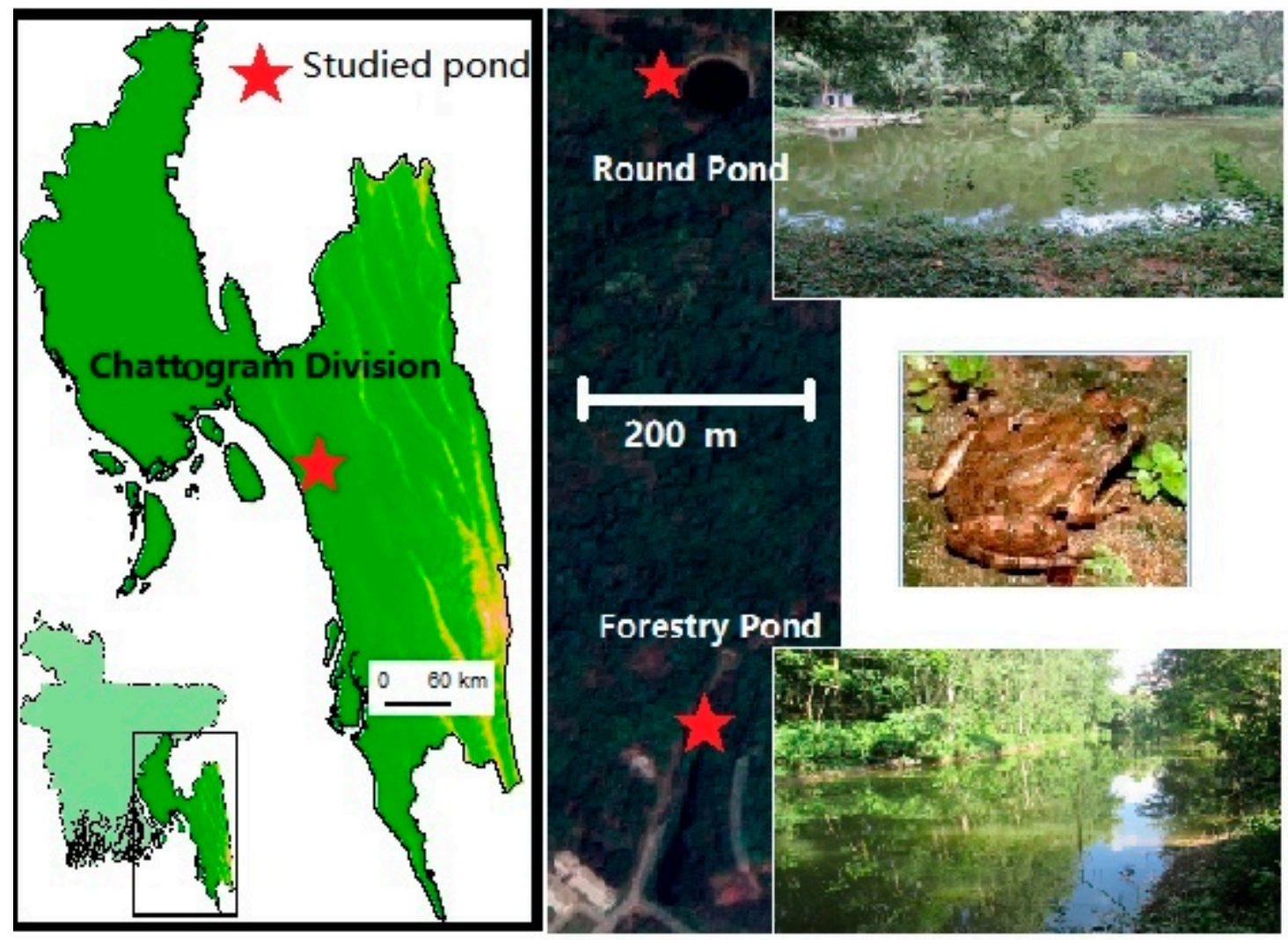

Figure 1. Map of Bangladesh and the location of the study area (asterisk) in the Southeastern Division of Bangladesh with a close view of the ponds. Inset: the common skipper frog (Euphlyctis cyanophlyctis).

\subsection{Data Collection}

We spent two to four days of every month collecting field data in 2013 and 2015. We maintained a minimum seven-day gap between two observation days, except September 2013, in which only one observation was made. Both ponds were sampled on each observation day. A total of 62 observations were considered, which covered the three basic seasons in Bangladesh (Supplementary Table S1). Of these, 16 observations were from summer, 30 from the rainy season and 16 were from winter. Seven habitat parameters were measured between 10:00-15:00 $\mathrm{h}$ of each observation day.

Temperatures were measured in the field by using a mercury thermometer calibrated from $0{ }^{\circ} \mathrm{C}$ to $110^{\circ} \mathrm{C}$, and $\mathrm{pH}$ was measured using an EZODO $6011 \mathrm{pH}$-meter. Dissolved oxygen was measured in the laboratory in milligrams per liter $(\mathrm{mg} / \mathrm{L})$ within $20 \mathrm{~min}$ of collection following the Winkler Azide method [30]. Plant species richness was determined by recording bank vegetation, and the macrophytes were identified to the species level using published keys [29]. The surface area and depth of the ponds were measured once a month using rope and measuring tape. During each observation, disturbance of the frogs was minimized by using a weak light beam, avoiding loud sounds, etc. A few specimens were collected and identified by following the taxonomic references of [31-34]. After identification, specimens were released to the source ponds. Individuals of Euphlyctis cyanophlyctis were counted by direct observation from after dusk until midnight (18:00-24:00) every observation day. Adult E. cyanophlyctis density (Ec_Den, number of adult individuals per unit area) was calculated from the total count of the frogs in the pond during each observation divided by the area of the pond. Due to low population size, the calculated frog population density per square meter was less than one, and hence we had to consider an "acre" as a unit area to express population density. Any observation regarding breeding activity, advertisement calls, and the presence of tadpoles were recorded for both ponds. 


\subsection{Analysis and Modeling}

The dataset of each pond was split into seven subsets. Three seasonal sub-datasets were analyzed in pairs, e.g., summer-rain, rain-winter, and winter-summer. Breeding season and non-breeding season datasets were analyzed to identify the differences between these two habitat states. Similarly, habitat states that supported population densities above the yearly mean values were denoted as the favorable habitat state, and the rest were denoted as unfavorable habitat states. A discriminant model was used to differentiate the habitat states at each site. The discriminant value of a parameter above 0.3 was considered as effective discrimination. The false-negative prediction of each discriminant model was recorded as sensitivity, while specificity was recorded to obtain the false positive prediction. Cross-validation value will indicate the prediction success of each model. These properties were analyzed to describe the contrast of the habitat states. Linear regression analysis was used to determine the combined influence of the studied factors on the fluctuation of the population density. To assess differences among sites and seasons, we used a two-sample $t$-test with an unequal variance of the frog density data. IBM ${ }^{\circledR}$ SPSS $^{\circledR}$ statistics 23.0 was used for statistical analyses.

\section{Results}

Seven habitat parameters $(\mathrm{n}=62)$, i.e., air and water temperature (AT and WT), $\mathrm{pH}$, dissolved oxygen (DO), depth and size of the water body (Depth and Size), plant species richness (PSR), were used as predictors and the density of the adult Euphlyctis cyanophlyctis (Ec_Den) was used as the response variable. These were analyzed to understand the relationship between the predictors and the frog density.

\subsection{Studied Ponds}

The fluctuations of air temperature (AT) were indistinguishable $(p>0.05)$ between ponds, while the temporal fluctuations of the remaining five predictors differed significantly between sites (Table 1 ). The discriminating analysis of the total data matrix (7 parameters $\times 62$ observations $\times 2$ sites) gave a clear indication of site-wise clustering of data (Figure 2). Ponds were distinct with no overlapping of observations with respect to discriminant function 1, which consisted of a significant contribution of $\mathrm{pH}$ and depth of the water body. The seasonal values of parameters in both sites were arranged similarly (Figure 2). Observations were partially overlapped as per discriminant function 2-significant contribution of temperature parameters. The sensitivity of the models documented the extent of this overlapping (Table 2). For instance, discrimination analysis found that $30 \%$ of the observations from the summer were statistically similar to the observations from the following rainy season in the round pond. The amount of similar false-positive seasonal observations from the forestry pond was $0 \%-20 \%$ (Table 2 ).

Table 1. Habitat predictors and the density of Euphlyctis cyanophlyctis in two ponds.

\begin{tabular}{ccccccc}
\hline \multirow{2}{*}{ Parameters } & \multicolumn{2}{c}{ Round Pond } & \multicolumn{2}{c}{ Forestry Pond } & \multicolumn{2}{c}{ Differences between Ponds } \\
\cline { 2 - 7 } & Range & Mean \pm SD & Range & Mean \pm SD & $t$-Value & $p$ Value \\
\hline Size $\left(\mathrm{m}^{2}\right)$ & 2375.83 & 8093.7 & 0.42 & $p>0.05$ \\
\hline $\mathrm{AT}\left({ }^{\circ} \mathrm{C}\right)$ & $24.00-35.00$ & $30.50 \pm 3.05$ & $24.00-35.00$ & $30.27 \pm 3.00$ & 2.52 & $p<0.05$ \\
\hline $\mathrm{WT}\left({ }^{\circ} \mathrm{C}\right)$ & $13.00-34.50$ & $27.04 \pm 5.74$ & $13.00-34.50$ & $24.29 \pm 6.41$ & 10.67 & $p<0.001$ \\
\hline $\mathrm{pH}$ & $4.89-7.90$ & $6.39 \pm 0.74$ & $4.15-7.10$ & $5.13 \pm 0.57$ & $p<0.001$ \\
\hline DO $(\mathrm{mg} / \mathrm{L})$ & $3.29-8.90$ & $6.96 \pm 1.55$ & $2.50-6.97$ & $5.05 \pm 1.01$ & 18.92 & $p<0.001$ \\
\hline Depth $(\mathrm{m})$ & $1.77-3.79$ & $2.54 \pm 0.47$ & $0.34-2.10$ & $0.95 \pm 0.47$ & -5.22 & $p<0.001$ \\
\hline PSR & $13.00-28.00$ & $19.79 \pm 5.97$ & $15.00-37.00$ & $26.27 \pm 7.73$ & 0.05 & $p>0.05$ \\
\hline Ec_den (no./acre) & $0.00-39.00$ & $14.79 \pm 10.44$ & $0.00-51.00$ & $14.70 \pm 13.13$ & 0.13 & \\
\hline
\end{tabular}

$\mathrm{AT}=$ air temperature, $\mathrm{WT}=$ water temperature, $\mathrm{DO}=$ dissolved oxygen. $\mathrm{PSR}=$ plant species richness. Ec_den = Euphlyctis cyanophlyctis density. 


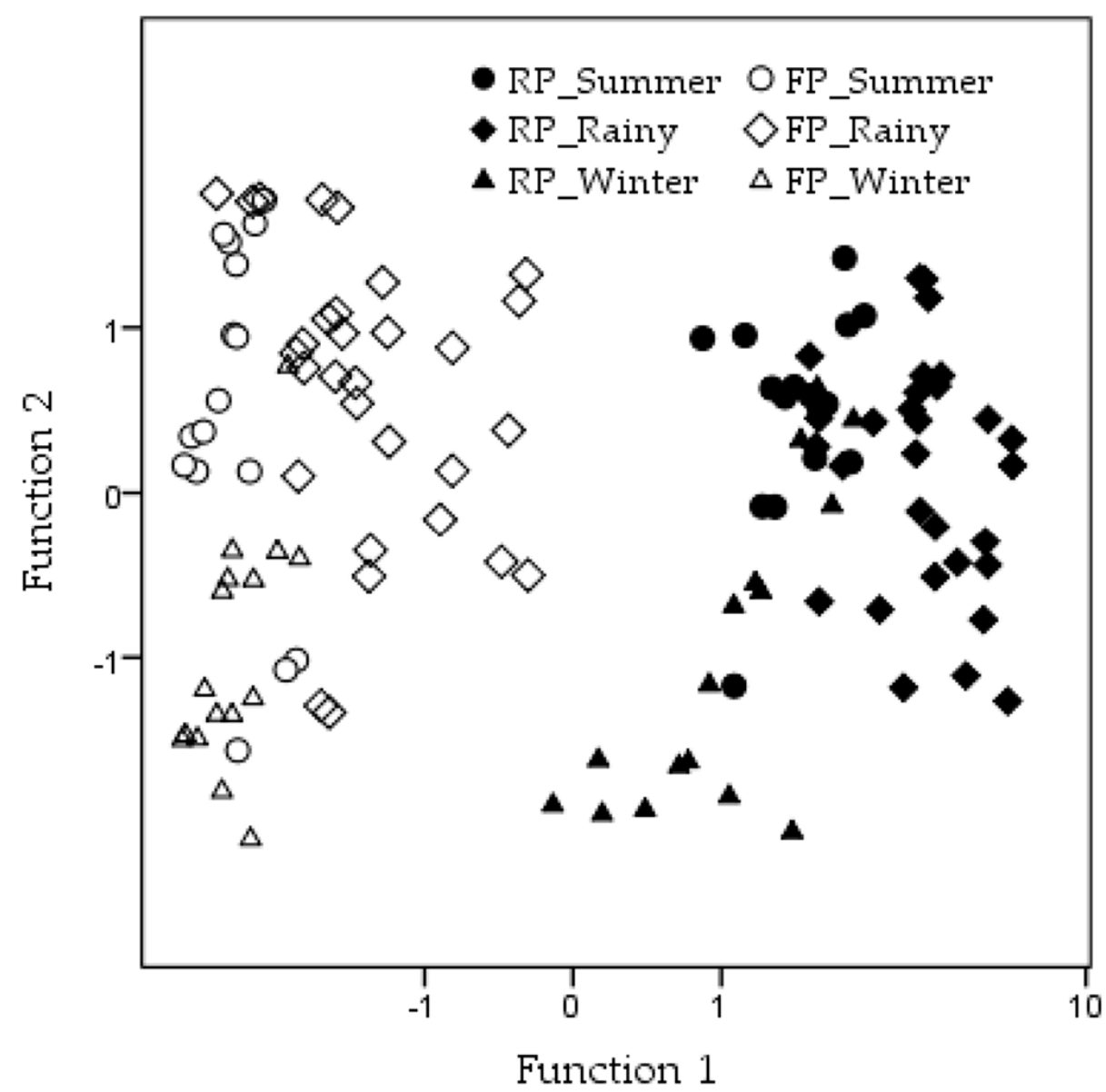

Figure 2. Scatter plot of 62 observations with two canonical discriminant functions (log scale display). Function $1=0.177 \mathrm{AT}-0.063 \mathrm{WT}+0.479 \mathrm{pH}^{*}+0.336 \mathrm{DO}+0.867 \mathrm{depth}^{*}-0.035$ PSR. Function $2=$ $0.426 \mathrm{AT}^{*}+0.772 \mathrm{WT}^{*}-0.522 \mathrm{pH}+0.244 \mathrm{DO}-0.074$ depth $-0.257 \mathrm{PSR}^{*}=p \leq 0.05$.

\subsection{Fluctuations of Frog Population}

The yearly mean population density of the common skipper frog (Ec_den) was 15 frogs per acre at both sites. The studied frog population was below the yearly mean value in $44 \%$ of observations in the round pond and $32 \%$ observation in the forestry pond, and there were notable wide fluctuations with zero values (Table 1). The frog densities at a site differed significantly between any two seasons. Summer at both sites had a higher density of frogs than the other two seasons, and the lowest population was recorded in the rainy season at both sites (Figure 3). The monthly population curve rose twice in a year, i.e., in early summer (March onwards) and again in early winter (October onwards). Due to the higher accommodation capacity, the second and last quarters of the year were denoted as favorable habitat states for analysis (marked in Figure 3). The Ec_den was low, and frequently zero occurrences of frogs were recorded during the third quarter of the year, which was selected as an unfavorable habitat state.

The population differed significantly between seasonal habitat states as well as between the aforesaid habitat conditions (favorable and unfavorable). The monsoon season, July to September, is the breeding season of the common skipper frog [35-37]. Population sizes in the breeding season and the non-breeding season differed significantly in the round pond, while in the forestry pond, the difference was insignificant, although the population size was lower in the breeding season at both sites. 


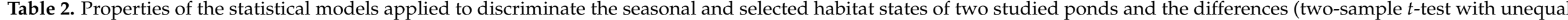
variance) in the abundance of Euphlyctis cyanophlyctis.

\begin{tabular}{|c|c|c|c|c|c|c|c|c|c|}
\hline 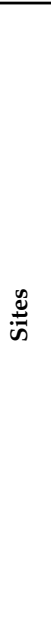 & 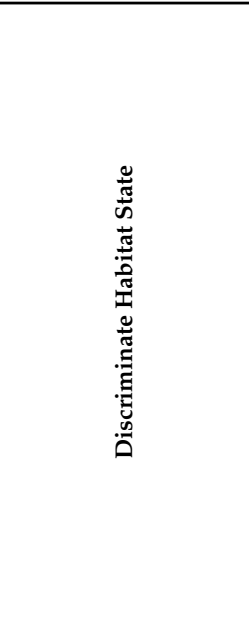 & 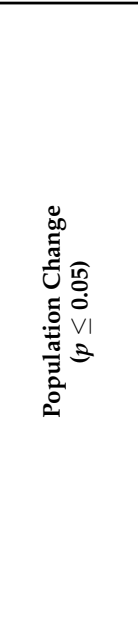 & 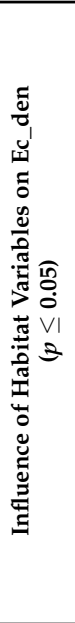 & 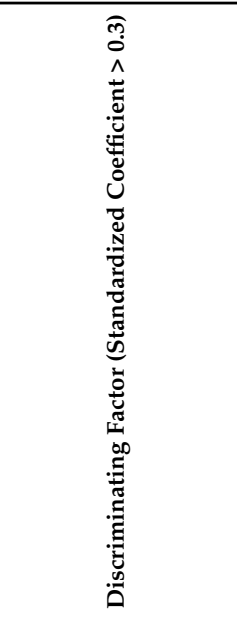 & 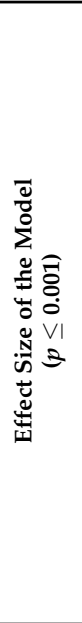 & 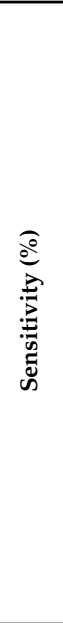 & 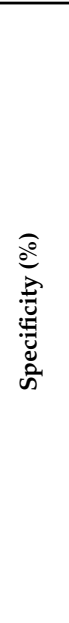 & 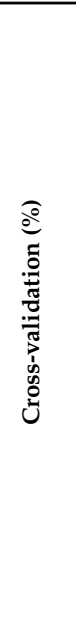 & 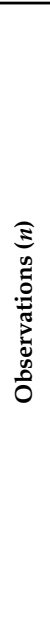 \\
\hline \multirow{4}{*}{ 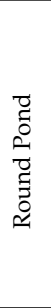 } & $\begin{array}{l}\text { Summer } \\
\text { and rainy }\end{array}$ & Decreased & Yes & Depth, pH, WT & 64.64 & 68.8 & 93.3 & 84.8 & 46 \\
\hline & Rainy and winter & Increased & Yes & WT, pH, DO, AT & 84.64 & 100 & 93.8 & 97.8 & 46 \\
\hline & $\begin{array}{c}\mathrm{F}^{1} \text { and } \\
\mathrm{UF}^{2}\end{array}$ & Decreased & Yes & pH, Depth, WT, PSR & 40.96 & 74.4 & 84.2 & 77.4 & 62 \\
\hline & NBS $^{3}$ and BS ${ }^{4}$ & Decreased & Yes & $\mathrm{pH}, \mathrm{WT}$, Depth & 64.32 & 82.9 & 92.6 & 87.1 & 62 \\
\hline \multirow{5}{*}{ 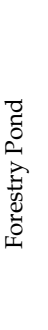 } & $\begin{array}{l}\text { Summer } \\
\text { and rainy }\end{array}$ & Decreased & Yes & Depth, pH & 63.20 & 81.3 & 80.0 & 80.4 & 46 \\
\hline & Rainy and winter & $\begin{array}{c}\text { Decreased } \\
p>0.05\end{array}$ & No & Depth, AT, WT & 79.21 & 96.7 & 87.5 & 93.5 & 46 \\
\hline & Winter and summer & Increased & Yes & PSR & 83.17 & 100 & 93.8 & 96.9 & 32 \\
\hline & $\begin{array}{l}\mathrm{F}^{1} \text { and } \\
\mathrm{UF}^{2}\end{array}$ & Decreased & Yes & Depth, WT & 55.95 & 95.0 & 72.7 & 87.1 & 62 \\
\hline & $\begin{array}{c}\text { NBS }^{3} \\
\text { and BS }{ }^{4}\end{array}$ & $\begin{array}{c}\text { Decreased } \\
p>0.05\end{array}$ & No & Depth, WT & 60.68 & 85.7 & 81.5 & 83.9 & 62 \\
\hline
\end{tabular}

Ec_den $=$ density of Euphlyctis cyanophlyctis, ${ }^{1}$ and ${ }^{2}=$ favorable and unfavorable habitat states, ${ }^{3}$ and ${ }^{4}=$ non-breeding and breeding season habitat states. 

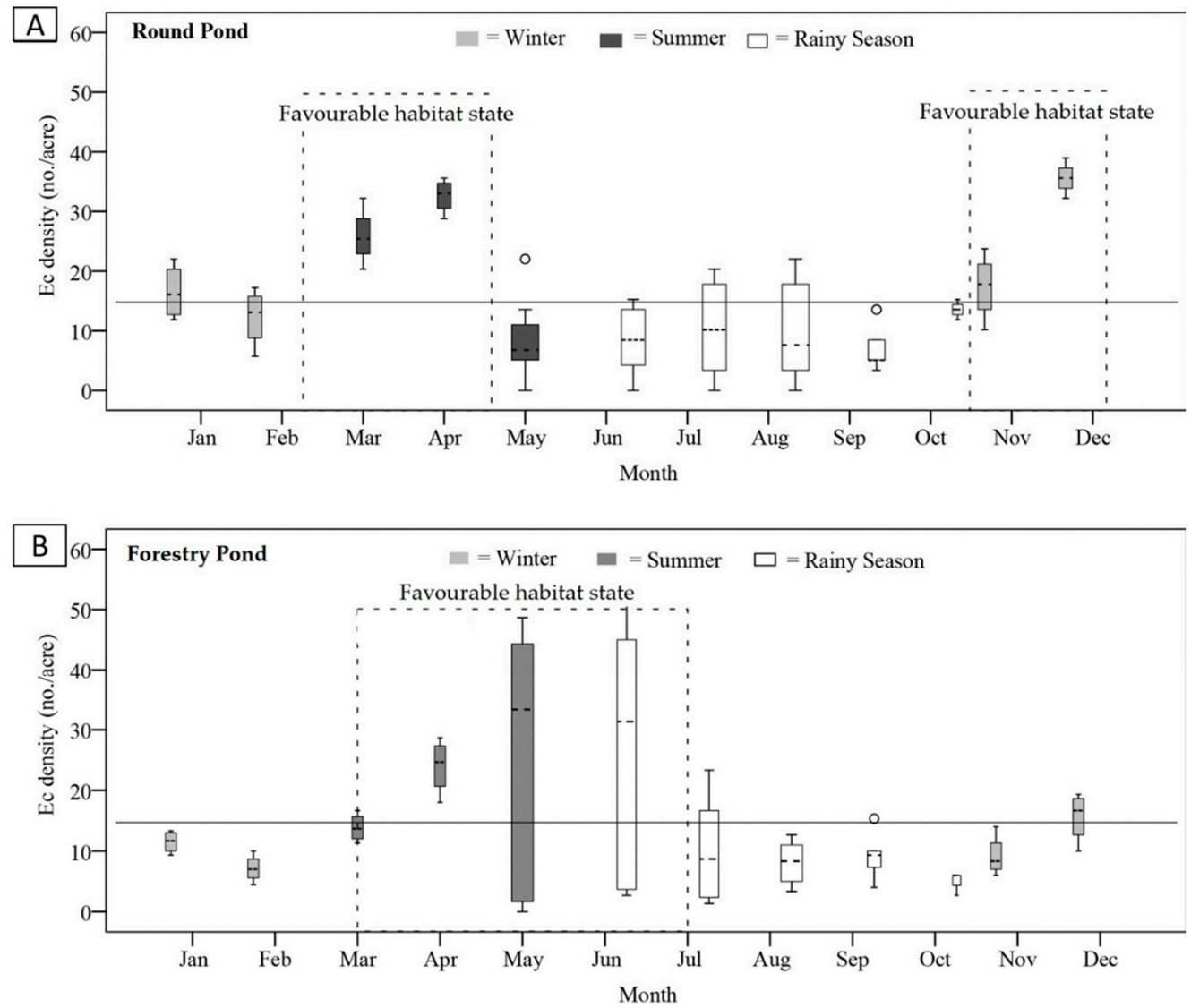

Figure 3. Monthly mean abundance of Euphlyctis cyanophlyctis in the round pond (A) and in the forestry pond (B). Width of the boxplot is proportional to the number of observations. The horizontal line presents the mean annual population density.

\subsection{Discriminant Parameters between Habitat States}

The cumulative influence of the parameters of seasonal habitat states of each site on the frog density in the respective season was significant $(p<0.05)$, except during wintersummer in the round pond, and rain-winter in the forestry pond (Table 2). In the rainy season, $\mathrm{pH}$ and depth values were higher than the values in summer at each site. The water depth of both ponds increased in the monsoon and decreased during the dry season. In addition, higher water temperature and more plant species in the summer and rainy seasons were the discriminating factors between these seasons and winter at both sites (Table 2).

Analysis of favorable and unfavorable habitat states revealed that $\mathrm{WT}, \mathrm{pH}$, depth, and PSR were the most discriminating parameters between these two density-depended habitat states in the round pond. In forestry pond, WT and depth contributed significantly to the disparity between these two habitat states. High frog density was associated with the lower numerical values of WT, pH, depth, and PSR in the round pond and water depth in the forestry pond (Table 3). Similarly, lower values of the abovementioned parameters in the non-breeding season could accommodate a comparatively higher density of frogs than in the breeding season. Specifically, a habitat of $24^{\circ} \mathrm{C}$ means water temperature with around $\mathrm{pH} 6$ and $2.29 \mathrm{~m}$ mean water depth in the round pond was associated with a high frog density ( 24 frogs per acre). In forestry pond, 27 frogs per acre were recorded in a habitat with less than $1 \mathrm{~m}$ mean water depth and an average $27^{\circ} \mathrm{C}$ water temperature. These two combinations were the optimum combination in studied ponds. On the other hand, $26-35^{\circ} \mathrm{C} \mathrm{WT}$, $\mathrm{pH}$ less than 6 , and a pond with a depth greater than $3.5 \mathrm{~m}$ with dense 
growth in the littoral zone were found to have a negative impact on the population during the breeding season in the round pond.

Table 3. The mean and standard deviation of the influential parameters and their cumulative influence on the frog density in the selected habitat states of each pond.

\begin{tabular}{|c|c|c|c|c|c|c|}
\hline \multicolumn{7}{|c|}{ Round Pond (Mean \pm SD) } \\
\hline Habitat States & WT & $\mathrm{pH}$ & Depth & PSR & Ec_den & Adj. $R^{2}$ \\
\hline Favorable habitat & $24.05 \pm 4.33$ & $5.92 \pm 0.57$ & $2.29 \pm 0.22$ & $17.37 \pm 3.27$ & $24.14 \pm 9.85$ & $0.542 *$ \\
\hline Unfavorable habitat & $28.37 \pm 5.83$ & $6.60 \pm 0.71$ & $2.65 \pm 0.51$ & $20.86 \pm 6.59$ & $10.66 \pm 6.73$ & $0.370 * * *$ \\
\hline Breeding season & $30.96 \pm 2.10$ & $6.97 \pm 0.53$ & $2.86 \pm 0.49$ & & $9.17 \pm 6.94$ & $0.568^{* * *}$ \\
\hline Non-breeding season & $24.02 \pm 5.85$ & $5.94 \pm 0.54$ & $2.29 \pm 0.25$ & & $19.13 \pm 10.69$ & $0.063(p>0.05)$ \\
\hline \multicolumn{7}{|c|}{ Forestry Pond (Mean \pm SD) } \\
\hline Habitat States & WT & Depth & Ec_den & Adj. $R^{2}$ & & \\
\hline Favorable habitat & $27.56 \pm 4.28$ & $0.70 \pm 0.47$ & $27.14 \pm 14.35$ & $0.811^{* * *}$ & & \\
\hline Unfavorable habitat & $22.49 \pm 6.71$ & $1.08 \pm 0.42$ & $7.85 \pm 4.84$ & $0.675^{* * *}$ & & \\
\hline Breeding season & $27.46 \pm 5.66$ & $1.30 \pm 0.41$ & $13.48 \pm 13.93$ & $0.755^{* * *}$ & & \\
\hline Non-breeding season & $21.84 \pm 5.91$ & $0.67 \pm 0.30$ & $15.63 \pm 12.60$ & $0.604^{* * *}$ & & \\
\hline
\end{tabular}

\section{Discussion}

The analysis of seven parameters showed that both ponds in the current study were distinctly different, and hence they function as different systems (Figure 2). In spite of the difference in size and shape of the ponds, the density of plants in the littoral zone appeared to be similar in both ponds $[23,25]$. Within a site, the discriminating factors between seasonal habitat conditions demonstrated that the same factor did not characterize the habitat in every season, and each factor has differing effects on the frog population throughout the year (discriminating factors in Table 2). Similar to the present observations, low densities of this species have been described in the eastern and western corners of its range (5-10/acre in Islamabad, Pakistan, [13,38]; 10-14/acre from Chittagong, Bangladesh [39]), but the frog is widely distributed [15,40-42].

In the current study, the population increase in early summer was due to the tendency of this frog to flock to the permanent water bodies after the less active winter season and the first showers of the year, cf. [24]. Our data support the conclusion that the depth of the water in early summer is comparatively low, and the adults of this species prefer the littoral zone over deep water [37]. The littoral macrophytes are a favorable location in which the adults can hide and lay eggs [43]. In the present study, slightly higher values of temperature, $\mathrm{pH}$, and depth in the rainy season compared to that of summer were found to have a negative impact on the adult frogs. Though the ambient temperature was above $30^{\circ} \mathrm{C}$ during summer and the monsoon season, the depth of the water rose close to four meters in the round pond and two meters in the forestry pond during the rainy season. During this season, heavy rainfalls increase the depth of water rapidly, and due to the straight banks, the shallow littoral zone is further submerged. The soil minerals are washed away and mixed into the pond water, which may increase turbidity and $\mathrm{pH}$ [27]. Khan et al. [27] recorded almost neutral $\mathrm{pH}(6.86-7.80)$ in the round pond, which matched with the $\mathrm{pH}$ values recorded in the rainy season in the current study. In forestry pond, this parameter also increased during the monsoon season but remained below six. Amphibian abundance has a clear negative correlation with low and high $\mathrm{pH}$ values, which may affect the population size [44]. Increasing the $\mathrm{pH}$ in the studied ponds might change the habitat suitability, making it uncomfortable for adults [2], especially during the rainy season [5]. In round pond, the littoral plants may provide shelter to the adult in increasing depth in the rainy season, and hence PSR is an influential variable for the suitability of the habitat of 
E. cyanophlyctis in this pond. In contrast, the floral richness is not necessarily influential in the forestry pond as this pond has shallow water depth $(0.34-2.10 \mathrm{~m})$. Data on predation was limited to a couple of sightings. Of the 62 sampling days, we found only two predation events of water scorpions (Nepa sp.) on young skipper frogs from the studied ponds [20]. Previously, water bugs (Lethocerus spp.) were known to be predators of larval and adult anurans, including E. cyanophlyctis $[45,46]$, but were not found in the present study sites. There was no fish at either site. More habitat parameters need to be examined to precisely understand the seasonal habitat in the ponds.

During the breeding season, the advertisement call and tadpoles were absent from the permanent ponds, though the breeding activities and advertisement call of E. cyanophlyctis in other permanent ponds were well documented $[47,48]$. Contrastingly, breeding activities and successful development of tadpoles were also witnessed in small waterholes, ditches and paddies, and roadside drains in the current study area $[49,50]$. The advertisement calls of this anuran were mostly recorded from the shallow and temporary water bodies in the Chattogram division [50]. Previous studies recorded a higher density of the common skipper frog (10-1002 individuals per acre) in four shallow water bodies than that in three permanent ponds (3-558 individuals per acre) within the current study area [23]. Those shallow waterholes are used as the breeding site for six anurans, including E. cyanophlyctis [39]. Contrasting to the present study, the $\mathrm{pH}$ of those water holes fluctuates between 6 and 7, and the depth is always less than $1 \mathrm{~m}$ [39]. These features of the temporary water holes are preferred by breeders, which are absent in our study ponds. Those temporary forms of shallow water bodies (lasting until early winter) appeared due to accumulating rainwater, and they were observed to be a refuge for the adults and had successful tadpole growth. Tadpoles of this frog prefer shallow water to facilitate their feeding habit [37]. Before the disappearance of those temporary waterholes, the completion of metamorphosis can be explained by the plasticity of the amphibians [51]. In winter, those temporary shallow habitats dry out, and the adults migrate to the permanent water bodies such as our study ponds. This reflects the increase in the population density in the study ponds and causes the second population increase in both ponds (Figure 3). Our findings suggest that in the rainy season, both ponds should be considered temporarily not suitable habitat. The failure of permanent ponds to provide a suitable breeding environment has not been described before in Bangladesh.

The use of temporary water bodies for a short period in the life cycle of the skipper frog helped it to overcome problems with the unsuitable condition of the permanent habitats [52]. Both ponds and temporary waterholes received a similar amount of human stimuli, e.g., situated within ten meters of a road with a limited vehicle and human movement. In addition, minimal amounts of swimming take place in the round pond. Unlike permanent ponds, the temporary water holes are subject to frequent human-induced landscape changes, which may impact frog abundance [53]. The number of temporary waterholes is decreasing in number due to plantation activities, construction, and land alteration in the study area as well as in the rest of Bangladesh [54,55]. Our study has pointed out that protecting the temporary habitats might create a refuge for the frogs during the temporary unfavorable conditions of the permanent water habitat [52].

Out of the 49 amphibian species occurring in Bangladesh, 33\% are under threatened and data-deficient statuses [15]. In the latest red list assessment, four aspects of the population category were assessed: generation length, total population, number of subpopulations, and population trends. These categories were noted as "not known" in the case of every amphibian in Bangladesh [15]. This assessment indicated the absence of research on amphibian population dynamics and the detailed description of the associated habitats in Bangladesh. A similar scenario is present in many countries, which causes misleading conservation statuses of the species [9]. Amphibian taxa have a high risk of extinction largely due to habitat-related reasons [56]. Our findings highlight that adult Euphlyctis cyanophlyctis select shallow water bodies to breed. Moreover, in order to assess the conservation status of a species accurately, we suggest (i) details of the fluctuation of 
a population, and (ii) responsible states of microhabitat must be considered [57]. Studies on habitat-population relationships that consider more parameters may better explain the influence of habitat conditions on anuran population fluctuation.

\section{Conclusions}

The present study concluded that permanent water bodies provide suitable habitats for Euphlyctis cyanophlyctis, but these become unfavorable in their breeding season. The variation in the parameters of the permanent habitat during the rainy season may have an effect on its accommodation capacity. The impact might be a synergistic influence of temperature, $\mathrm{pH}$, and depth of the water or individual effects of any of these factors. In the rainy season, adults take refuge in ephemeral water bodies, which are, in turn, vulnerable to anthropogenic disturbance. We suggest maintaining some temporal waterholes adjacent to the permanent habitat to compensate for the impact of the seasonal deformation in those habitats on adult frogs. We also suggest that the seasonal population density of a frog species should be identified besides its annual population status. Similar studies are needed for the understudied amphibians of Bangladesh, and such works in combination may help to improve conservation efforts.

Supplementary Materials: The following are available online at https://www.mdpi.com/2673-413 $3 / 2 / 1 / 7 / s 1$, Table S1: Collected data on variables and frog density from two studied ponds.

Author Contributions: M.A.W.C. developed the concept, methods, conducted the statistical analysis, prepared and finalized figures and draft, and supervised the total study. S.R.S. and M.M.R. developed the method, collected and analyzed the data, and reviewed the draft. All authors have read and agreed to the published version of the manuscript.

Funding: This research received no external funding.

Conflicts of Interest: The authors declare no conflict of interest.

\section{References}

1. Stuart, S.N.; Chanson, J.S.; Cox, N.A.; Young, B.E.; Rodrigues, A.S.L.; Fischman, D.L.; Waller, R.W. Status and Trends of Amphibian Declines and Extinctions Worldwide. Science 2004, 306, 1783-1786. [CrossRef]

2. Evans, M.J.; Scheele, B.C.; Westgate, M.J.; Yebra, M.; Newport, J.S.; Manning, A.D. Beyond the pond: Terrestrial habitat use by frogs in a changing climate. Biol. Conser. 2020, 249, 108712. [CrossRef]

3. Schmidt, K.; Richards, S.; Pearson, R.G.; Alford, R.A.; Puschendorf, R. Seasonal, annual and decadal change in tadpole population in tropical Australian streams. Amphib. Reptil. 2019, 40, 447-459. [CrossRef]

4. Brandão, R.A.; Fenker, J.; Lopes, B.E.P.d.C.; de Sena, V.M.d.A.; Vasconcelos, B.D. Diet of terrestrial anurans in an ephemeral and simplified habitat during the dry season in the Brazilian Cerrado. Ethol. Ecol. Evol. 2020, 32, 527-550. [CrossRef]

5. Zhang, W.; Li, B.; Shu, X.; Pei, E.; Yuan, X.; Sun, Y.; Wang, T.; Wang, Z. Responses of anuran communities to rapid urban growth in Shanghai, China. Urban For. Urban Green. 2016, 20, 365-374. [CrossRef]

6. Alford, R.A. Ecology: Resource use, competition, and predation. In Tadpoles: The Biology of Anuran Larvae; McDiarmid, R.W., Altig, R., Eds.; Chicago University Press: Chicago, IL, USA, 1999; pp. 240-278.

7. Lopez, J.E.; Pfister, C.A. Local population dynamics in metapopulation models: Implications for conservation. Conserv. Biol. 2001, 15, 1700-1709. [CrossRef]

8. Randall, L.A.; Smith, D.H.V.; Jones, B.L.; Prescott, D.R.C.; Moehrenschlager, A. Seasonal Differences in Extinction and Colonization Drive Occupancy Dynamics of an Imperilled Amphibian. PLoS ONE 2015, 10, e0127059. [CrossRef]

9. Ron, S.R.; Duellman, W.E.; Coloma, L.A.; Bustamante, M.R. Population Decline of the Jambato Toad Atelopus ignescens (Anura: Bufonidae) in the Andes of Ecuador. J. Herpetol. 2003, 37, 116-126. [CrossRef]

10. Orizaola, G.; Dahl, E.; Laurila, A. Compensating for delayed hatching across consecutive life-history stages in an amphibian. Oikos 2010, 119, 980-987. [CrossRef]

11. Narzary, J.; Bordoloi, S. A study on certain common pond breeding anurans and their tadpoles in a pond of western Assam, India. Int. J. Adv. Biol. Res. 2012, 2, 342-348.

12. Banks, B.; Beebee, T.J.C. Factors influencing breeding site choice by the pioneering amphibian Bufo calamita. Holarct. Ecol. 1987, 10, 14-21. [CrossRef]

13. Akram, A.; Rais, M.; Asadi, M.A.; Jilani, M.J.; Balouch, S.; Anwar, M.; Saleem, A. Do habitat variables correlate anuran abundance in arid terrain of Rawalpindi-Islamabad areas, Pakistan. J. King Saud Univ. Sci. 2015, 27, 278-283. [CrossRef]

14. Pearman, P.B. Effects of habitat size on tadpole populations. Ecology 1993, 74, 1982-1991. [CrossRef] 
15. IUCN Bangladesh. Red List of Bangladesh, Volume 4: Reptiles and Amphibians; IUCN: International Union for Conservation of Nature, Bangladesh Country Office: Dhaka, Bangladesh, 2015; p. 336.

16. Mahony, S.; Hasan, M.K.; Kabir, M.M.; Ahmed, M.; Hossain, M.K. A catalogue of amphibians and reptiles in the collection of Jahangirnagar University, Dhaka, Bangladesh. Hamadryad 2009, 34, 80-94.

17. Alam, M.S.; Igawa, T.; Khan, M.M.R.; Islam, M.M.; Kuramoto, M.; Matsui, M.; Kurabayashi, A.; Sumida, M. Genetic divergence and evolutionary relationships in six species of genera Hoplobatrachus and Euphlyctis (Amphibia: Anura) from Bangladesh and other Asian countries revealed by mitochondrial gene sequences. Mol. Phylogenet. Evol. 2008, 48, 515-527. [CrossRef] [PubMed]

18. Howlader, M.S.; Nair, A.; Gopalan, S.V.; Merila, J. A new species of Euphlyctis (Anura: Dicroglossidae) from Barisal, Bangladesh. PLoS ONE 2015, 10, e0116666. [CrossRef] [PubMed]

19. Ghose, A.; Deb, J.C.; Dakwa, K.B.; Ray, J.P.; Reza, A.H.M.A. Amphibian species assemblages in a tropical forest of Bangladesh Herpetol. J. 2017, 27, 318-325.

20. Khan, M.S. A new subspecies of common skittering frog Euphlyctis cyanophlyctis (Schneider 1799) from Balochistan, Pakistan. Pak. J. Zool. 1997, 29, 107-112.

21. Joshy, S.H.; Alam, M.S.; Kurabayashi, A.; Sumida, M.; Kuramoto, M. Two new species of the genus Euphlyctis cyanophlyctis (Anura, Ranidae) from south-western India, revealed by molecular and morphological comparisons. Alytes 2009, $26,97-116$.

22. Priti, H.; Naik, C.R.; Seshadri, K.S.; Singal, R.; Vidisha, M.K.; Ravikanth, G.; Gururaja, K.V. A New Species of Euphlyctis (Amphibia, Anura, Dicroglossidae) from the West Coastal Plains of India. Asian Herp. Res. 2016, 7, 229-241.

23. Shil, S.R. Analysis of Habitat Preference of Some Anurans (Family: Dicroglossidae) of the Chittagong University Campus, Chittagong; Unpublished M.S. Project 2014; Department of Zoology, University of Chittagong: Chattogram, Bangladesh, $2014 ;$ p. 52.

24. Chowdhury, M.A.W.; Rahman, M.M.; Khan, M.A.G. Influence of habitat parameters on Common Skipper Frog (Euphlyctis cyanophlyctis) in Chittagong. Bangladesh J. Zool. 2016, 44, 133-146. [CrossRef]

25. Rahman, M.M. Habitat Ecology of Common Skipper Frog (Euphlyctis cyanophlyctis) (Schneider, 1799) of the Chittagong University Campus, Chittagong, Bangladesh. Master's Thesis, Department of Zoology, University of Chittagong, Chattogram, Bangladesh, 2016; p. 73, Unpublished M.S. Dissertation.

26. Islam, A.T.M.; Chowdhury, M.S.; Hoque, A.K.M.M.; Malek, S.A. Detailed Soil Survey Chittagong University Campus; Department of soil Survey: Dhaka, Bangladesh, 1979; p. 208.

27. Khan, M.A.G.; Nath, S.K.; Sadique, S.B.; Biswas, S.C. Limnological conditions of three ponds and ecology of their macrobenthic invertebrates. Bangladesh J. Zool. 2007, 35, 1-17.

28. Ahmed, N. Geography of East Pakistan; Oxford University Press: Oxford, UK, 1968; p. 361.

29. Alam, M.N.; Pasha, M.K. A floristic account of Chittagong University Campus. Chittagong Univ. J. Sci. 1999, $23,81-98$.

30. American Public Health Association. Standard Methods for the Examination of Water and Waste Water, 21st ed.; APHA-AWWA-WEF: Washington, DC, USA, 2005; p. 541.

31. Dubois, A.; Ohler, A. Frogs of the subgenus Pelophylax (Amphibia, Anura, genus Rana). Zool. Pol. 1995, 39, 139-204.

32. Khan, M.S.; Mufti, S.A. Oropharyngeal morphology of detritivorous tadpole of Rana cyanophlyctis Schneider, and its ecological correlates. Pak. J. Zool. 1995, 27, 43-49.

33. Das, I.; Dutta, S.K. Checklist of the amphibians of India, with English common names. Hamadryad Madras 1998, $23,63-68$.

34. Chakma, S. Euphlyctis cyanophlyctis. In Encyclopedia of Flora and Fauna of Bangladesh. Amphibian and Reptiles; Kabir, S.M.H., Ahmed, A.T.A., Rahman, A.K.A., Ahmed, Z.U., Begum, Z.N.T., Hassan, M.A., Khondker, M., Eds.; Asiatic society of Bangladesh: Dhaka, Bangladesh, 2009; Volume 25, pp. 9-10.

35. Pancharatna, M.; Saidapur, S.K. Ovarian cycle in the frog Rana cyanophlyctis: A quantitative study of follicular kinetics in relation to body mass, oviduct, and fat body cycles. J. Morphol. 1985, 186, 135-147. [CrossRef] [PubMed]

36. Pawar, V.G.; Pancharatna, K. Annual oviduct cycle in the Indian skipper frog, Rana cyanophlyctis (Schneider 1799): A morphological study. Trop. Zool. 1999, 12, 79-88. [CrossRef]

37. Mahapatra, S.; Rout, J.; Sahoo, G.; Sethy, J. Dietary preference of Euphlyctis cyanophlyctis tadpoles in different habitats in and around Similipal biosphere reserve, Odisha, India. Int. J. Cons. Sci. 2017, 8, 259-268.

38. Tabassum, F.; Rais, M.; Anwar, M.; Mehmood, T.; Hussain, I.; Khan, S.A. Abundance and Breeding of the Common Skittering Frog (Euphlyctis cyanophlyctis) and Bull Frog (Hoplobatrachus tigerinus) at Rawal Lake, Islamabad, Pakistan. Asian Herp. Res. 2011, 2, 177-250.

39. Chowdhury, M.A.W.; Das, M.C. Habitat Selection and Population Ecology of Six Winter Active Anurans (Class: Amphibia) of the Chittagong University Campus. Bangladesh J. Environ. Sci. 2014, 26, 67-74.

40. Khan, M.S.; Papenfuss, T.; Anderson, S.; Rastegar-Pouyani, N.; Kuzmin, S.; Dutta, S.; Manamendra-Arachchi, K.; Sharifi, M. Euphlyctis cyanophlyctis. In The IUCN Red List of Threatened Species, Errata Version Published in 2016; Red List: Cambridge, UK, 2009.

41. Khan, M.Z.; Mahmood, N.; Ghalib, S.A.; Hussain, B.; Siddiqui, S.; Perween, S.; Abbas, D. Impact of habitat destruction on the population of amphibians with reference to current status of frogs and toads in Karachi and Thatta, Sindh. Can. J. Pure Appl. Sci. 2010, 4, 1257-1265.

42. Pal, A.; Dey, S.; Roy, U.S. Seasonal diversity and abundance of herpetofauna in and around an industrial city of West Bengal, India. J. Appl. Sci. Environ. Sanit. 2012, 7, 281-286.

43. Solomampianina, G.; Molnár, N. Occurrence of True Frogs (Ranidae L.) in the region of Szeged as related to aquatic habitat parameters. Tiscia 2011, 38, 11-18. 
44. Glos, J.; Grafe, T.U.; Rödel, M.-O.; Linsenmair, K.E. Geographic Variation in pH Tolerance of Two Populations of the European Common Frog, Rana temporaria. Copeia 2003, 3, 650-656. [CrossRef]

45. Figueiredo-de-Andrade, C.A.; Santana, D.J.; de Carvalho-e-Silva, S.P. Predation on Scinax x-signatus (Anura: Hylidae) by the giant water bug Lethocerus annulipes (Hemiptera: Belostomatidae) in a Brazilian Restinga habitat. Herpetol. Notes. 2010, 3, 53-54.

46. Dissanayake, D.S.B. Euphlyctis cyanophlyctis in Natural history notes. Herpetol. Rev. 2012, 43, 462-463.

47. Mahony, S.; Reza, A.H.M.A. A herpetofaunal collection from the Chittagong Hill Tracts, Bangladesh, with two new species records for the country. Hamadryad 2008, 32, 45-56.

48. Khan, M.A.R. Wildlife of Bangladesh: Checklist-Cum-Guide; Alam, M.J., Ed.; Chayabithi: Dhaka, Bangladesh, 2015.

49. Kabir, S.M.H.; Ahmed, A.T.A.; Rahman, A.K.A.; Ahmed, Z.U.; Begum, Z.N.T.; Hassan, M.A.; Khondker, M. Encyclopedia of Flora and Fauna of Bangladesh, Volume 25: Amphibians and Reptiles; Asiatic society of Bangladesh: Dhaka, Bangladesh, 2009 ; Volume 25.

50. Chowdhury, M.A.W. Acoustic Analysis of the Amphibian Species Diversity in Chittagong Region. Master's Thesis, University of Chittagong, Chattogram, Bangladesh, 2009; p. 242, Unpublished M.Phil. Dissertation.

51. Griffiths, R.A. Temporary ponds as amphibian habitats. Aquatic Conserv. Mar. Freshw. Ecosyst. 2003, 7, 119-126. [CrossRef]

52. Hoffmann, E.P. Environmental watering triggers rapid frog breeding in temporary wetlands within a regulated river system. Wetlands Ecol. Manag. 2018, 26, 1073-1087. [CrossRef]

53. Li, B.; Zhang, W.; Wang, Z.; Xie, H.; Yuan, X.; Pei, E.; Wang, T. Effects of landscape heterogeneity and breeding habitat diversity on rice frog abundance and body condition in agricultural landscapes of Yangtze River Delta, China. Cur. Zool. 2020, 1-9. [CrossRef] [PubMed]

54. Breininger, D.R.; Mazerolle, M.J.; Bolt, M.R.; Legare, M.L.; Drese, J.H.; Hines, J.E. Habitat fragmentation effects on annual survival of the federally protected eastern indigo snake. Anim. Conser. 2012, 15, 361-368. [CrossRef]

55. Rahman, M.T.U.; Tabassum, F.; Rasheduzzaman, M.; Saba, H.; Sarkar, L.; Ferdous, J.; Uddin, S.Z.; Islam, A.Z.M.Z. Temporal dynamics of land use/land cover change and its prediction using CA-ANN model for southwestern coastal Bangladesh. Environ. Monit. Assessm. 2017, 189, 565. [CrossRef] [PubMed]

56. Gallant, A.L.; Klaver, R.W.; Casper, G.S.; Lannoo, M.J. Global rates of habitat loss and implication for amphibian conservation. Copeia 2007, 4, 967-979. [CrossRef]

57. IUCN Standards and Petitions Subcommittee. Guidelines for Using the IUCN Red List Categories and Criteria; Version 13; Prepared by the Standards and Petitions Subcommittee; Red List: Cambridge, UK, 2017. 